\title{
Reproductive Components of Safflower Genotypes Submitted of Bulk Density Levels in the Brazilian Cerrado
}

\author{
Juliana Terezinha Sasso Paludo1, Edna Maria Bonfim-Silva1*, \\ Tonny José Araújo da Silva1, Maurício Dutra Zanotto², William Fenner ${ }^{3}$, Marcio Koetz ${ }^{1}$
}

${ }^{1}$ Department of Agricultural and Environmental Engineering, Institute of Agricultural Sciences and Technology-ICAT, Federal University of Mato Grosso-UFMT, Cuiabá, Brazil

${ }^{2}$ Faculty of Agronomic Sciences of Botucatu, Paulista State University Júlio de Mesquita Filho-UNESP, Botucatu, Brazil ${ }^{3}$ Faculty of Agronomy and Zootechnic-FAAZ, Post Graduating in Tropical Agriculture, Federal University of Mato Grosso-UFMT, Cuiabá, Brazil

Email: *embonfim@hotmail.com

How to cite this paper: Paludo, J.T.S., Bonfim-Silva, E.M., da Silva, T.J.A., Zanotto, M.D., Fenner, W. and Koetz, M. (2017) Reproductive Components of Safflower Genotypes Submitted of Bulk Density Levels in the Brazilian Cerrado. American Journal of Plant Sciences, 8, 2069-2082. https://doi.org/10.4236/ajps.2017.89139

Received: July 13, 2017

Accepted: August 1, 2017

Published: August 4, 2017

Copyright (c) 2017 by authors and Scientific Research Publishing Inc. This work is licensed under the Creative Commons Attribution International License (CC BY 4.0).

http://creativecommons.org/licenses/by/4.0/

\begin{abstract}
Nutrient absorption in crops can decline and their development can be hindered by increased bulk density. This study aimed at assessing the manner in which bulk density levels affect the reproductive structures of the safflower genotypes in the Brazilian Cerrado. The completely randomized design was adopted with four replications for the experiment, which was conducted in a greenhouse using Oxisol collected from 0.0 to $0.2 \mathrm{~m}$ depth from the region supporting Cerrado vegetation. The treatments included ten safflower genotypes (PI 237538, PI 248385, PI 250196, PI 301049, PI 305173, PI 305205, PI 306520, PI 306603, PI 560202 and PI 613366) and five bulk density levels (1.0, $1.2,1.4,1.6$ and $1.8 \mathrm{Mg} \cdot \mathrm{m}^{-3}$ ). Evaluations were done at 90 days after emergence, in terms of the number, diameter and dry mass of the heads. The data were submitted to the analysis of variance. The means were grouped using the Scott-Knott test at 5\% probability. The diameter and dry mass of the chapters were influenced by the mean bulk density of $1.10 \mathrm{Mg} \cdot \mathrm{m}^{-3}$. A notable interaction was evident between the safflower genotypes and bulk density levels for the diameter and dry mass of the head alone, revealing the high degree of genetic variability that environmental changes induce among the genotypes. The PI 250196, PI 301049, PI 305173 and PI 305205 genotypes exhibited greater stability to the bulk density variations compared with the others. Mean bulk density of $1.2 \mathrm{Mg} \cdot \mathrm{m}^{-3}$ was found to impair the development of the reproductive components of the safflower genotypes.
\end{abstract}




\section{Keywords}

Carthamus tinctorius L., Bulk Density, Oleaginous Crop, Safflower Genotypes, Physical Attributes of Soil

\section{Introduction}

The study of soil physical quality assumes great significance as it directly hinders crop yield [1]. Soil compaction can hinder the water and nutrient uptake in plants, thus inhibiting their development [2] [3] [4], besides undermining the root system aeration and obstructing the suiting development. Intensification of bulk density can curtail the macro-porosity, lower the infiltration rate and minimize the morphological changes in the roots of the cultivated plants [3] [5]. Therefore, accurate soil and crop management is vital, as soil compaction is virtually inescapable in modern [6].

As safflower (Carthamus tinctorius L.), belonging to family Asteraceae [7], is oleaginous, its seeds are potential raw material in the production of biodiesel and manufacture of paints and varnishes [8], with its substantial oil content (35\% to $45 \%$ ), being a high additional value [9].

This usually culture presents a 110 to 150 days cycle, which may be shorter or longer, based on the genotype and prevailing environmental factors [7] [10]. The rosette stage is distinguished by slow plant growth and the emergence of leaves closer to the ground. This is a three to six-week phase, contingent upon the genetic material and environment to which they are exposed, temperature in particular [7].

Stem elongation and the ramifications indicate the more intensive growth phases of the plant, and last between 6 and 8 weeks [11]. The flowering commences between 60 and 100 days, and extends outwards, with the flower stage persisting from 14 to 21 days, depending on the edaphoclimatic conditions [8] [12]. The flowers are normally in hues of yellow, orange and red but rarely white. However, they change to other colors as they wilt [13].

The plant reaches physiological maturity between 4 and 6 weeks once the flowering phase begins [14], and the ideal harvesting time is between 2 and 3 weeks post maturity [11]. This culture showed high adaptability to extreme environmental conditions, thriving in semi-arid areas as well as at altitudes ranging from sea level to $2000 \mathrm{~m}$ [11].

The Brazilian Cerrado is characterized by predominantly deep and well drained Oxisols. The pluviometric pattern of this region experiences two distinct seasons, a rainy season, between October and March and a dry one, from May to September. The transition periods between the seasons is between March and May, and September to October [15].

In pioneering study in the Cerrado region, researchers affirm that the Brazilian biome offers suitable conditions for the safflower culture to adapt itself for 
cultivation, particularly during the off-season period [2]. Safflower is a suitable alternative for diversification in the agricultural sector during that season, once that strong rainfall during the flowering period could hinder pollination and result in a low safflower grain yield [16].

The studies conducted in Brazil focusing on the critical bulk density levels in the safflower crop continue to remain rare, particularly in terms of the reproductive constituents of the plants. However, this is fundamental to understanding the adaptation of the safflower genotypes in the Brazilian Cerrado. This study aimed at assessing the ways that the bulk density levels affect the reproductive components of the safflower genotypes in this region.

\section{Material and Methods}

To determine the response of the reproductive parts of the safflower genotypes to various bulk density levels, ten safflower genotypes (PI 237538, PI 248385, PI 250196, PI 301049, PI 305173, PI 305205, PI 306596, PI 306603, PI 560202 and PI 613366) were studied at five bulk density levels (1.0, 1.2, 1.4, 1.4 and 1.8 $\mathrm{Mg} \cdot \mathrm{m}^{-3}$ ), through artificial compaction. All the genotypes, supplied by the MatoGrossense Cotton Institute (IMA), were reared under greenhouse conditions, adopting a completely randomized design, which included 10 safflower genotypes and 5 densities of 4 replicates, comprising 200 experimental units in total. During this period, the mean temperature and relative humidity were maintained at $28.4^{\circ} \mathrm{C}$ and $67.8 \%$, respectively.

For this study, the soil used in the experimental units was brought from an area supporting the natural vegetation of the Cerrado, taken from the layer 0.0 to $0.2 \mathrm{~m}$ deep and sieved through a $4.00 \mathrm{~mm}$ mesh. The soil was classified as Oxisol [17] and the results of the chemical and granulometric soil analysis shows in Table 1.

Liming was then done to increase the base saturation to $60 \%$, and the soil was left packaged in plastic bags for continued reaction. At planting, fertilizers were added, including $200 \mathrm{mg} \cdot \mathrm{dm}^{-3}$ of nitrogen as urea, $150 \mathrm{mg} \cdot \mathrm{dm}^{-3}$ of phosphorus $\left(\mathrm{P}_{2} \mathrm{O}_{5}\right)$ as single superphosphate and $200 \mathrm{mg} \cdot \mathrm{dm}^{-3}$ of potassium $\left(\mathrm{K}_{2} \mathrm{O}\right)$ as potassium chloride [2]. To meet the micronutrient demand, $15 \mathrm{mg} \cdot \mathrm{dm}^{-3}$ of FTE BR 12 was applied with a minimum guarantee of $9 \% \mathrm{Zn}, 1.8 \% \mathrm{~B}, 0.8 \% \mathrm{Cu}, 2 \% \mathrm{Mn}$, $3.5 \% \mathrm{Fe}, 0.1 \% \mathrm{Mo}$.

The experimental units included a rigid PVC pot involving three rings, each of which were $200 \mathrm{~mm}$ in diameter and $100 \mathrm{~mm}$ in height, with a volume of

Table 1. Granulometric characterization and chemical analysis of the soil collected from the layer at 0.0 to $0.2 \mathrm{~m}$ depth.

\begin{tabular}{cccccccccccccc}
\hline $\mathrm{pH}$ & Sand & Silt & Clay & $\mathrm{P}$ & $\mathrm{K}$ & $\mathrm{Ca}$ & $\mathrm{Mg}$ & $\mathrm{H}$ & $\mathrm{Al}$ & $\mathrm{SB}$ & $\mathrm{CEC}$ & $\mathrm{V}$ & O.M. \\
\hline $\mathrm{CaCl}_{2}$ & & $\mathrm{~g} \cdot \mathrm{kg}^{-1}$ & & \multicolumn{3}{c}{$\mathrm{mg} \cdot \mathrm{md}^{-3}$} & & & $\mathrm{cmol}_{\mathrm{c}} \mathrm{dm}^{-3}$ & & & $\%$ & $\mathrm{~g} \cdot \mathrm{dm}^{-3}$ \\
\hline 4.0 & 423 & 133 & 444 & 1.4 & 23 & 0.4 & 0.2 & 5.4 & 0.8 & 0.7 & 6.8 & 9.7 & 27.1 \\
\hline
\end{tabular}

SB: Base Sum; CEC: Cation Exchange Capacity; V\%: Base Saturation; O.M.: Organic Matter. 
$9.423 \mathrm{~d} \cdot \mathrm{m}^{-3}$ (Figure 1 ), to establish the density desirable for each soil layer. These rings were attached using adhesive tape, and one end was covered with a 1 $\mathrm{mm}$ thick polyethylene sheet to prevent soil loss. Once the soil was filled, the experimental units were conditioned using a $300 \mathrm{~mm}$ plastic dish [4].

At sowing time, 20 seeds were planted per pot to ensure emergence, and superficial soil irrigation was performed until the plants were established, at around 15 days. From then on, water was supplied via capillarity to induce the plants to deepen their roots against the compacted layer to seek more water [18]. After plant emergence, the excess plants were removed at 5, 7 and 15 days after emergence, leaving ten, six and two plants in each plot, respectively, at the end of the third thinning process (Figure 2).

Data was collected at 90 DAE for the variables mentioned: Number of Heads $(\mathrm{NH})$-Diameter of Heads $(\mathrm{DH})$-which is the mean diameter of five heads per plot (mm) (Figure 3) and Dry Head Mass (DHM)-which is the dry mass of the total number of heads in each plot, dried in a forced air circulation oven at $65^{\circ} \mathrm{C}$ until constant mass was achieved.

The data were submitted of ANOVA and when significant, polynomial regression analysis was done for the bulk density levels and the Scott-Knott test for the genotypes. The analyses were performed using the Sisvar program considering $5 \%$ as the error probability [19].

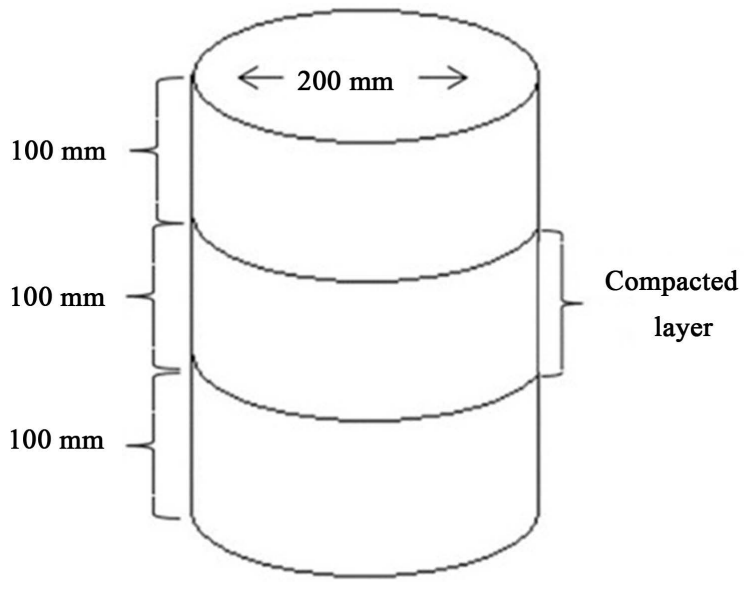

Figure 1. Representation of an experimental unit with its three soil layers.

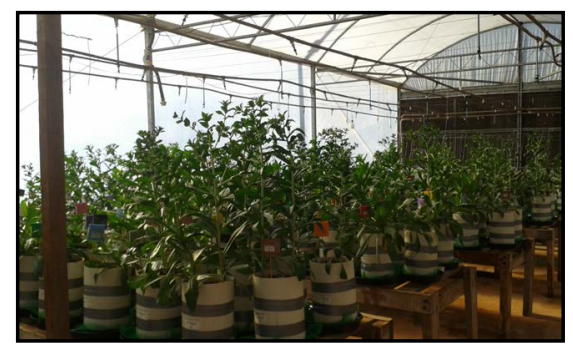

(a)

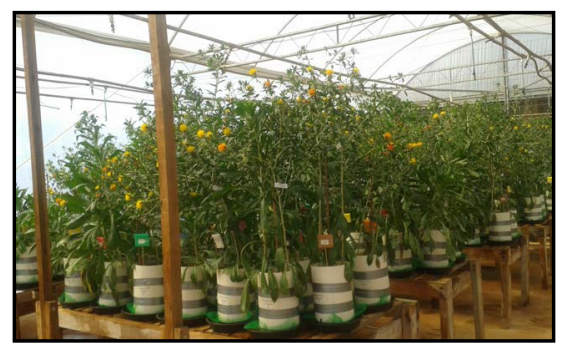

(b)

Figure 2. General view of the experiment at 37 (a) and 60 (b) days after sowing the safflower genotypes. 


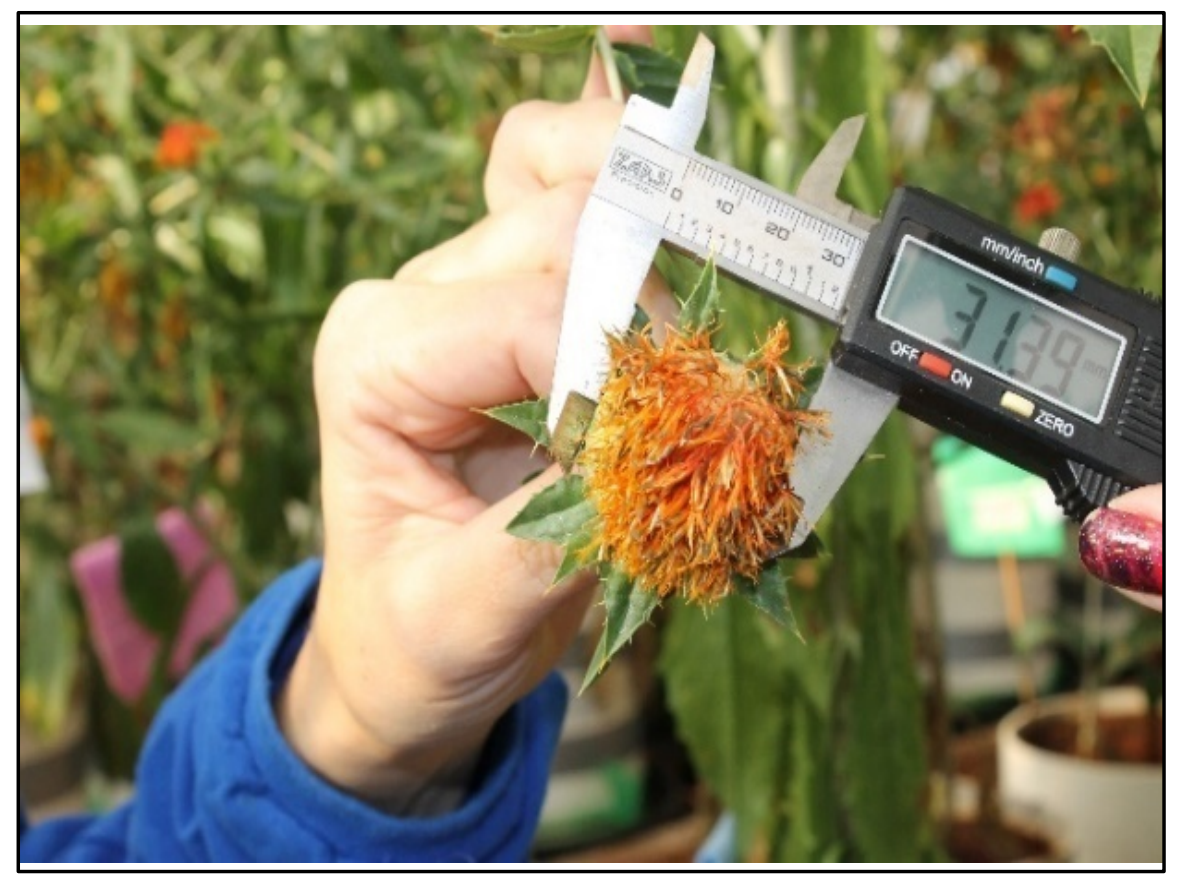

Figure 3. Diameter readings of the safflower heads.

\section{Results and Discussion}

Only the variables of head diameters (HD) and dry heads mass (DHM) revealed noteworthy interactions between the genotypes in response to the bulk density levels. The high genotypic variability was interesting from the perspective of the adaptability of the safflower crop to the different environmental conditions, as this enables the study of the adequacy of the genotypes under specific conditions, rationally using the environmental and financial resources.

\subsection{Number of Heads}

An isolated effect was noted for the number of heads for the genotypes and bulk densities studied (Figure 4 and Figure 5).

For the variable number of safflower heads of the genotypes can be categorized into three groups, as follows: the first group included the PI 237538, PI 248385, PI 301049, PI 305173 and PI 305205 genotypes, exhibiting the highest number of heads, (approximately 45 chapters on average per experimental unit); the second group included the PI 250196, PI 306596, PI 306603 and PI 560202 genotypes (showing an average of 28 chapters per experimental unit); and the third group included only one, (the PI 613366 genotype), bearing 8 chapters on average per experimental unit. This deficient performance is a result of the disease attack from the initial development phase, in which this genotype was less tolerant than the other genotypes.

The quadratic regression model includes the response of the number of heads to the bulk density, showing that the plant exhibited the best production of the heads for the $1.13 \mathrm{Mg} \cdot \mathrm{m}^{-3}$ density with a mean of 44.34 units per pot (Figure 5). 


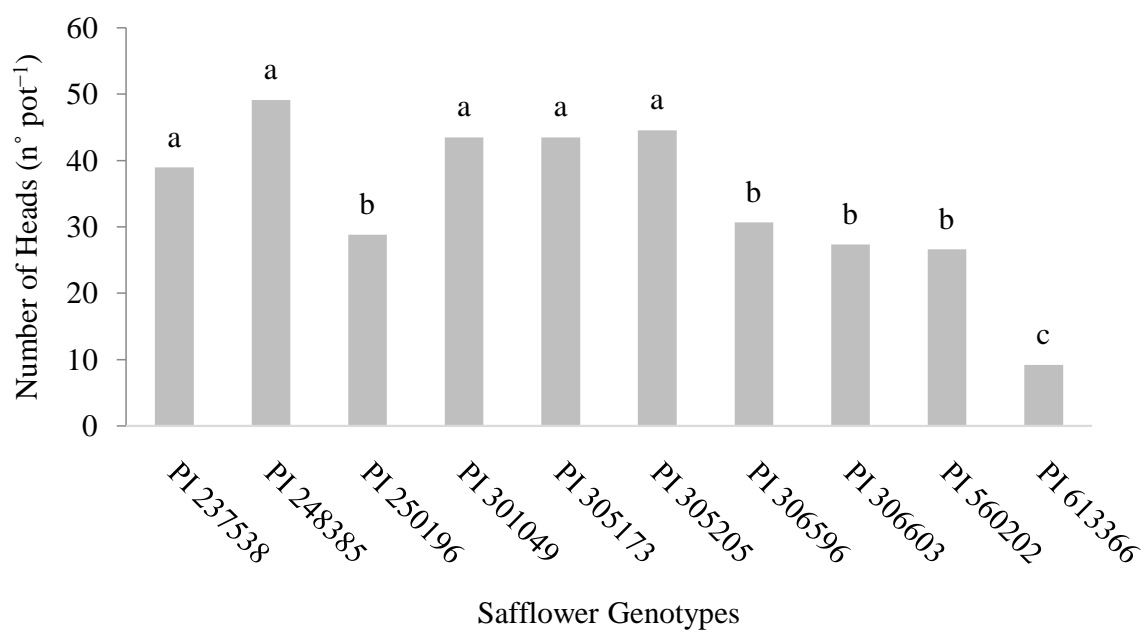

Figure 4. Number of heads of the safflower genotypes under study. Means followed by the same lowercase letter do not differ by Scott-Knott test at 5\% probability.

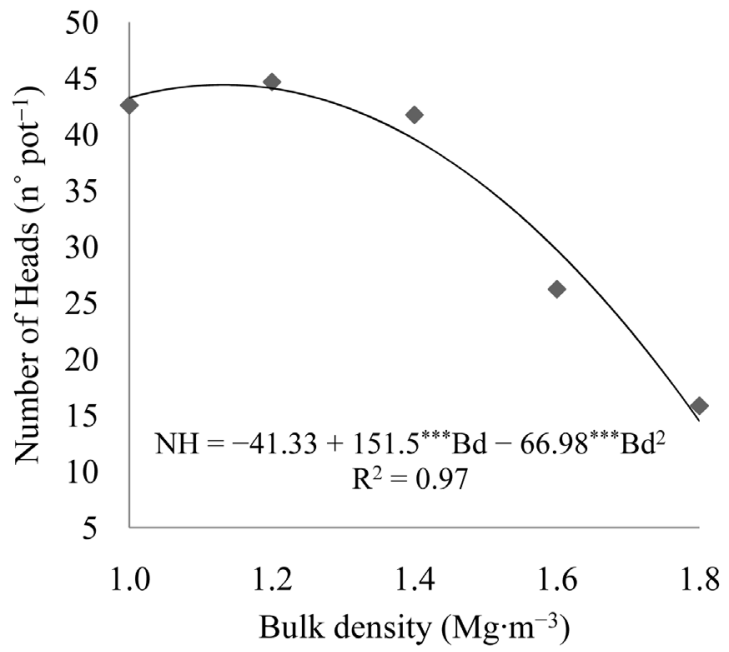

Figure 5. Number heads of safflower genotype in response to the bulk density levels. $\mathrm{NH}-\mathrm{Number}$ of heads; Bd-Bulk density. ${ }^{* *}$ Significant at $0.1 \%$ probability by the $\mathrm{F}$ test.

One of the crucial variables in the selection of the safflower genotypes is the number of heads, which is directly linked to the final crop production. In the case of the number of heads, a narrow bulk density range is recorded, while for the higher values $\left(1.13 \mathrm{Mg} \cdot \mathrm{m}^{-3}\right)$ the number of heads drops significantly up to a density of $1.80 \mathrm{Mg} \cdot \mathrm{m}^{-3}$. This action is most likely related to the stress of water and nutrient absorption by the crop, apart from the difficulties and energy expenditure in the effort to break through the compacted layer.

Confirming the findings for density, was reported developmental limitations in the morphological and productive characteristics in pig beans (Canavalia ensiformis) with increasing bulk density levels [20].

The root expansion into the deeper and compacted soil layers might be linked to improved exploration of the soil volume, which in turn raises the degree of water and nutrient absorption in these layers [21]. In this context, was confirmed 
lower levels of soil porosity, hydraulic conductivity and soil permeability due to machine traffic [22]. The authors indicated that such changes significantly influence the capacity for flow and soil transport. Therefore, selecting safflower genotypes possessing such features will subsequently result in the best expression of the components produced and improved adaptability of the crop in the area.

The reduction of the water availability for the safflower crop can compromise the stem elongation phase, indicated as one of the most sensitive to the water deficit, which, consequently, will result in a lower vegetative development and reproductive components [23].

Thus, the genotypes exhibiting the most number of branches and heads per plant should be chosen for the selection programs to ensure enhanced grain yield [24]. In fact, study have been reported that the most important variable for improved safflower crop yield is the number of heads per plant [25].

\subsection{Head Diameter}

At 90 days after plant emergence, the variable head diameters revealed a strong relationship between the safflower genotypes and bulk densities (Table 2).

Linked to the heads diameters of the safflower genotypes, it became clear that in the bulk density containing $1.0 \mathrm{Mg} \cdot \mathrm{m}^{-3}$ two groups emerged, the first had an average diameter of $22 \mathrm{~mm}$ produced by the PI 237538, PI 301049, PI 305173, PI 305205, PI 306596, PI 306603 and PI 560202 genotypes, while the second possessed a narrower mean diameter of $15.67 \mathrm{~mm}$ and was produced by the PI 248385, PI 250196 and PI 613366 varieties.

For the $1.2 \mathrm{Mg} \cdot \mathrm{m}^{-3}$ density two distinct groups were visible, one possessing the greatest diameter, produced by the PI 237538, PI 301049, PI 305173 and PI 560202 genotypes and the other, showing a narrower diameter produced by the PI 248385, PI 250196, PI 305205, PI 306596, PI 306603 and PI 613366 genotypes.

Table 2. Head diameter of the safflower genotypes submitted to bulk density (Bd) levels at 90 days after emergence.

\begin{tabular}{|c|c|c|c|c|c|c|c|c|c|c|}
\hline \multicolumn{11}{|c|}{ Safflower Genotypes (PI) } \\
\hline \multirow{2}{*}{$\mathrm{Bd}\left(\mathrm{Mg} \cdot \mathrm{m}^{-3}\right)$} & 237538 & 248385 & 250196 & 301049 & 305173 & 305205 & 306596 & 306603 & 560202 & 613366 \\
\hline & \multicolumn{10}{|c|}{ Head diameter(mm) } \\
\hline 1.0 & $22 \mathrm{~A}$ & $17 \mathrm{~B}$ & $16 \mathrm{~B}$ & $19 \mathrm{~A}$ & $19 \mathrm{~A}$ & $21 \mathrm{~A}$ & $20 \mathrm{~A}$ & $18 \mathrm{~A}$ & $21 \mathrm{~A}$ & $14 \mathrm{~B}$ \\
\hline 1.2 & $20 \mathrm{~A}$ & $18 \mathrm{~B}$ & $18 \mathrm{~B}$ & $20 \mathrm{~A}$ & $19 \mathrm{~A}$ & 17B & $17 \mathrm{~B}$ & $15 \mathrm{~B}$ & $21 \mathrm{~A}$ & 14B \\
\hline 1.4 & $19 \mathrm{~A}$ & 17B & $17 \mathrm{~B}$ & $17 \mathrm{~B}$ & $18 \mathrm{~B}$ & $20 \mathrm{~A}$ & $22 \mathrm{~A}$ & $18 \mathrm{~B}$ & $22 \mathrm{~A}$ & $13 \mathrm{~B}$ \\
\hline 1.6 & $19 \mathrm{~A}$ & $17 \mathrm{~A}$ & $15 \mathrm{~A}$ & $19 \mathrm{~A}$ & $19 \mathrm{~A}$ & $17 \mathrm{~A}$ & $19 \mathrm{~A}$ & $19 \mathrm{~A}$ & $22 \mathrm{~A}$ & $3 \mathrm{~B}$ \\
\hline 1.8 & $20 \mathrm{~A}$ & 15B & $12 \mathrm{~B}$ & $18 \mathrm{~A}$ & $18 \mathrm{~A}$ & $19 \mathrm{~A}$ & $18 \mathrm{~A}$ & $17 \mathrm{~A}$ & $19 \mathrm{~A}$ & $17 \mathrm{~A}$ \\
\hline Significant & \multicolumn{10}{|c|}{$* *$} \\
\hline CV (\%) & \multicolumn{10}{|c|}{17.35} \\
\hline
\end{tabular}

Means followed by the same letter in the rows do not differ statistically by the Scott-Knott test at the 5\% probability level. ${ }^{*}$ Significant at $1 \%$ probability, respectively, by the $\mathrm{F}$ test. 
At the $1.4 \mathrm{Mg} \cdot \mathrm{m}^{-3}$ bulk density the expression was identical to the previous densities, revealing two groups. The greatest diameter (19 to $22 \mathrm{~mm}$ ) was seen in the PI 237538, PI 305205, PI 306596 and PI 560202 genotypes, while the narrower one (13 to $18 \mathrm{~mm}$ ) was evident in the PI 248385, PI 250196, PI 301049, PI 305173, PI 306603 and PI 613366 genotypes.

In the case of the $1.6 \mathrm{Mg} \cdot \mathrm{m}^{-3}$ bulk density, only a single genotype, the PI 613366, was statistically different from the others, exhibiting a narrower head diameter. At the $1.8 \mathrm{Mg} \cdot \mathrm{m}^{-3}$ bulk density level, the PI 248385 and PI 250196 genotypes expressed the least chapter diameter of $13.5 \mathrm{~mm}$ on average when compared statistically with the other genotypes. The differences in the heads diameters in the safflower genotypes are clearly seen (Figure 6).

In study over three years, while assessing the variability of the yield stability in 25 safflower genotypes at five research stations, was reported that spatial variability was obvious in $50 \%$ of the cases, with the most stable genotypes producing the lowest yields. It is therefore clear that the high yielding genotypes respond specifically to the intrinsic conditions of their cultivation sites, vindicating the necessity for extensive research to endorse the same [26].

Regarding bulk density, the PI 250196 genotype adjusted to the quadratic regression model revealed that soil density levels influenced this variable (Figure 7). The greatest leaf diameter of $17.35 \mathrm{~mm}$ was recorded at $1.24 \mathrm{Mg} \cdot \mathrm{m}^{-3}$ bulk density; however, none of the other genotypes evaluated showed statistical difference.

The head diameter is the variable of highlighted and importance, once as the safflower culture has small heads, in which size bears a relation to the floral disk diameter [27]. The greater the head diameter, the more the number of flowers, the larger the quantity of inflorescence and, therefore, the higher the grain yield.

\subsection{Dry Head Mass}

An isolated effect was noted for the dry head mass for the different safflower genotypes and bulk density levels (Figure 8).

For the variable dry head mass, three groups emerged in which the first group including the PI 237538, PI 248385, PI 301049, PI 305173, PI 305205, PI 306596

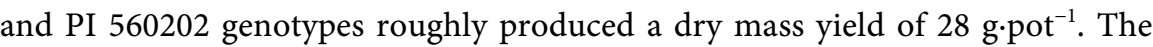
second group, including the PI 250196 and PI 306603 genotypes exhibited a dry mass yield of $18 \mathrm{~g} \cdot \operatorname{pot}^{-1}$, while the third group, which included only the PI 613366 genotype, showed a dry mass of $6.5 \mathrm{~g} \cdot \operatorname{pot}^{-1}$ (Figure 8).

With respect to the bulk density levels, an adjustment was made to the quadratic regression model (Figure 9).

For dry head mass, a yield of $34.07 \mathrm{~g} \cdot \mathrm{pot}^{-1}$ was noted for the $1.06 \mathrm{Mg} \cdot \mathrm{m}^{-3}$ bulk density; it was evident that as the bulk density increased the dry mass production of the heads decreased. It is Known that to plant roots break through the compacted soil layers, a high metabolic energy expenditure was required [28]. This was accomplished via the transport of photosynthesized material in the shoots of the aerial parts to the roots, resulting in lower yields. 


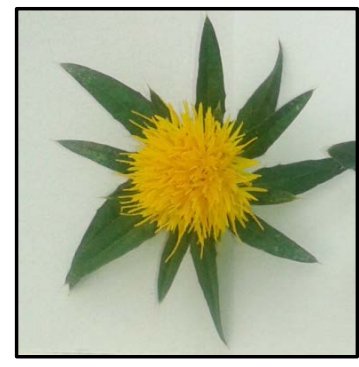

(a)

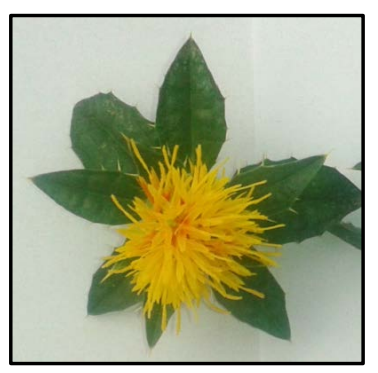

(c)

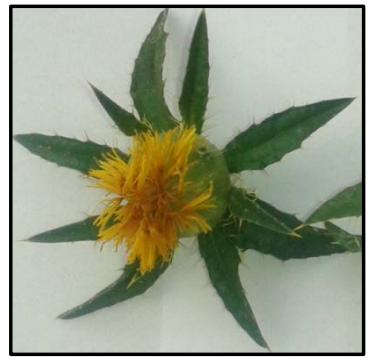

(e)

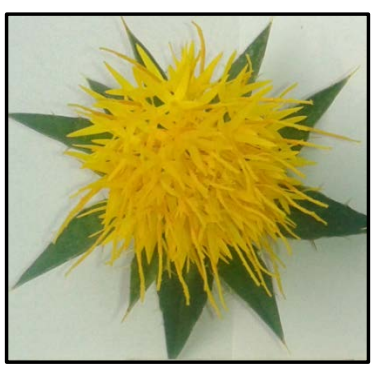

(g)

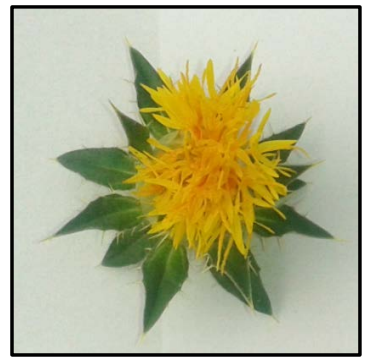

(i)

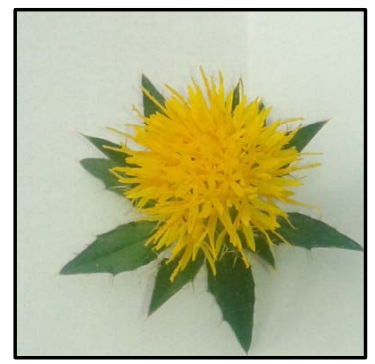

(b)

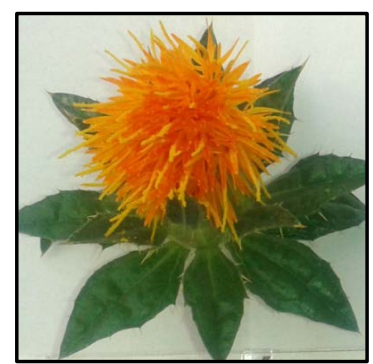

(d)

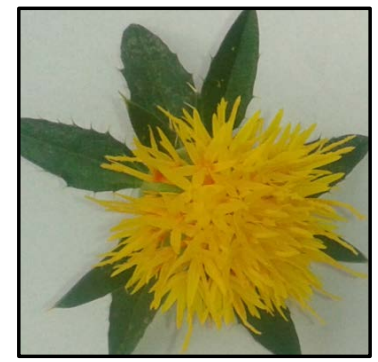

(f)

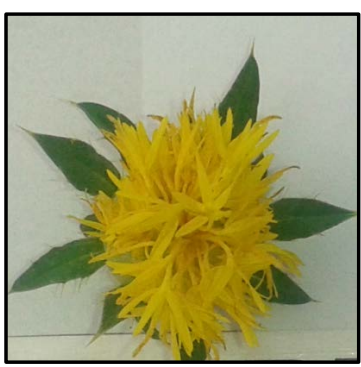

(h)

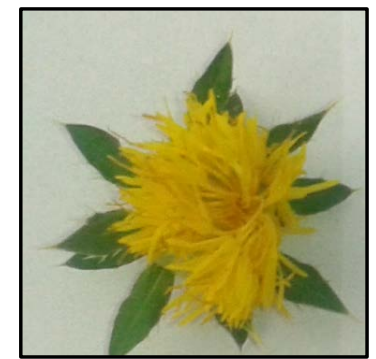

(j)

Figure 6. Variability of heads among the safflower genotypes (a) PI 237538; (b) PI 248385; (c) PI 250196; (d) PI 301049; (e) PI 305173; (f) PI 305205; (g) PI 306596; (h) PI 306603; (i) PI 560202 and (j) PI 613366. 


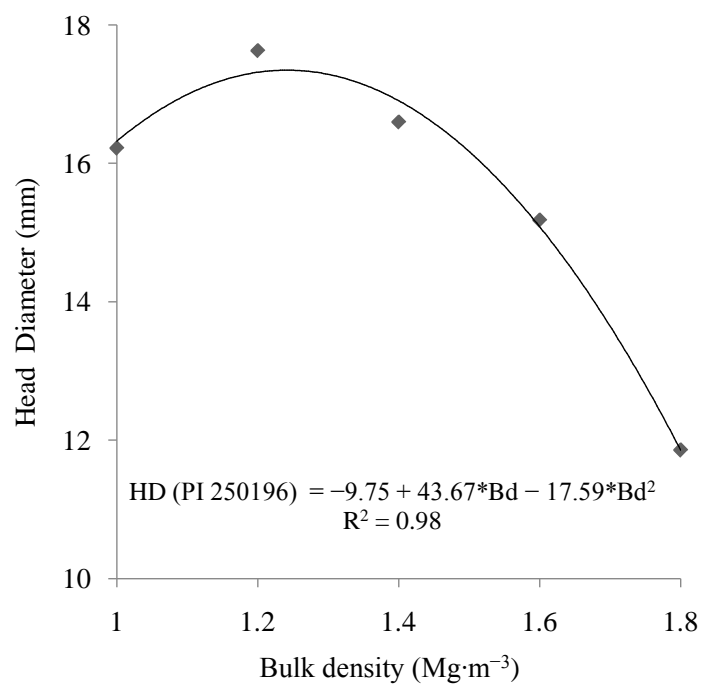

Figure 7. Head diameters of the safflower genotypes in response to the bulk density levels. HD-Head diameters; Bd-Bulk density. ${ }^{\star}$ Significant at $5 \%$ probability by the $\mathrm{F}$ test.

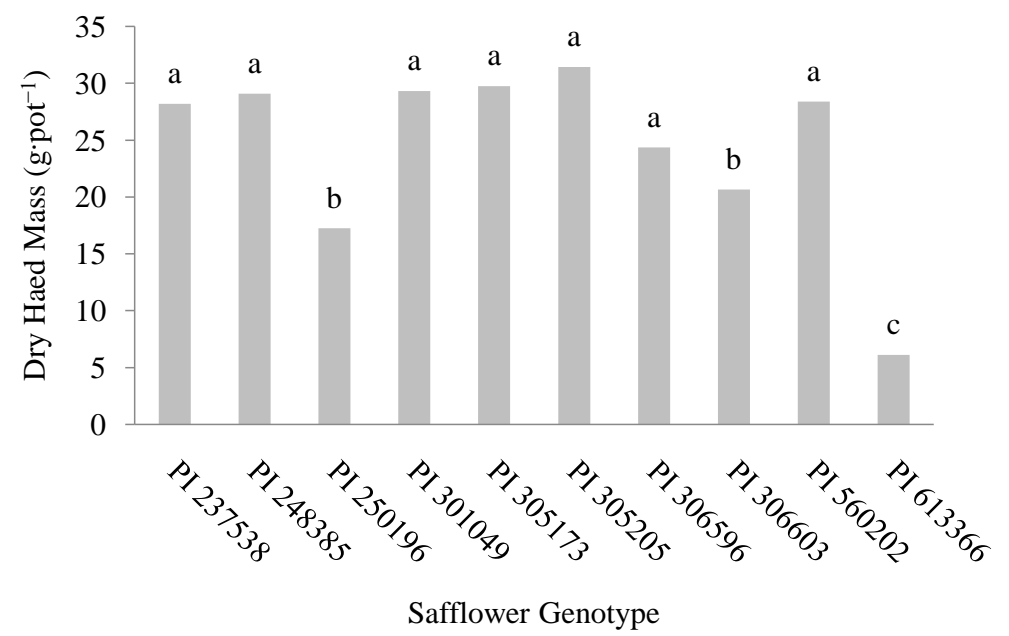

Figure 8. Dry head mass in the safflower genotype studied. Means followed by the same lowercase letter do not differ by the Scott-Knott test at $5 \%$ probability.

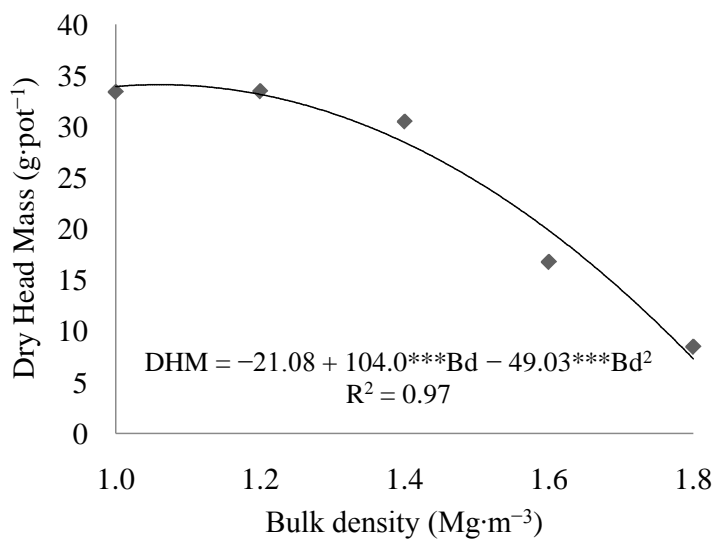

Figure 9. Dry head mass in the safflower genotype as a function of bulk density levels. DHM-Dry head mass; Bd-Bulk density. ${ }^{* * *}$ Significant at $0.1 \%$ probability by the $\mathrm{F}$ test. 
The development of cover crops under soil densities and resistance to penetration, provides significant reductions in dry mass production of rapeseed ( $R a$ phanus sativus) and black oats (Avena strigosa) at soil density of $1.34 \mathrm{Mg} \cdot \mathrm{m}^{-3}$ in Oxisol [29]. For maize (Zea mays L.) under different bulk density levels of the Oxisol, bulk densities greater than $1.21 \mathrm{Mg} \cdot \mathrm{m}^{-3}$ were found to be limiting to the growth [3]. Soil penetration resistance was pointed out as the main responsible for the lower plant development, even in comparison to the availability of water and nutrients [30]. Thus, it is evident the necessity of a correct management, aiming to assure the good vegetal development.

The bulk density negatively affects the phytometric components of the safflower crop. The mass of the safflower heads declined up to $53 \%$ compared with the densities of $1.0 \mathrm{Mg} \cdot \mathrm{m}^{-3}$ and $1.8 \mathrm{Mg} \cdot \mathrm{m}^{-3}$, irrespective of the nitrogen dose applied [4].

Normally, safflower is regarded as a sturdy plant with the capacity to tolerate environmental stresses like aridity and altitude, which has made it popular across the world. However, it was observed that the crop, despite its rusticity, has severe restrictions on the higher bulk density levels when considering the expression of the reproductive components, number, diameter and dry head mass.

Under bulk density conditions of $1.2 \mathrm{Mg} \cdot \mathrm{m}^{-3}$, all the variables analyzed showed a significant decline, which will certainly have negative repercussions in limiting the crop yield, irrespective of the genotype used. In this context, it can be established that as the bulk density intensifies, it impedes the water and nutrient absorption by the safflower plants, as well as induces a greater consumption of the photo as similates, which is expended on root growth to facilitate the search for nourishment, water and nutrients.

\section{Conclusions}

A notable interaction was recorded between the safflower genotypes and bulk density levels only for the variables of diameter and dry head mass, indicating a wide genetic variability among the genotypes during times of environmental alterations.

The PI 250196, PI 301049, PI 305173 and PI 305205 genotypes are found to be more stable to the bulk density variations when compared to the others.

Safflower genotypes show developmental impairments in their reproductive components under conditions of mean bulk density of $1.2 \mathrm{Mg} \cdot \mathrm{m}^{-3}$.

\section{Acknowledgements}

The authors thank the Brazilian National Council for Scientific and Technological Development (CNPq) and Coordination for the Improvement of Higher Education Personnel (CAPES) for providing scholarships to the authors, and the Mato-Grossense Cotton Institute (IMA) for providing safflower seeds.

\section{References}

[1] Leite, L.F.C., Arruda, F.P., Costa, C.N., Ferreira, J.S. and HolandaNeto, M.R. (2013) 
Chemical Quality of Soil and Dynamics of Carbon under Monoculture and Intercroping of Acrocomia Palm and Pasture. Revista Brasileira de Engenharia Agrícola e Ambiental, 17, 1257-1263.

http://www.scielo.br/pdf/rbeaa/v17n12/v17n12a02.pdf https://doi.org/10.1590/S1415-43662013001200002

[2] Bonfim-Silva, E.M., Paludo, J.T.S., Sousa, J.V.R., Sousa, H.H.F. and da Silva, T.J.A. (2015) Development of Safflower Subjected to Nitrogen Rates in Cerrado Soil. American Journal of Plant Sciences, 6, 2136-2143. https://doi.org/10.4236/ajps.2015.613215

[3] Nunes, J.A.S.,Bonfim-Silva, E.M. and Silva, T.J.A. (2016) Bulk Density and Water Tensions in the Soil on Corn Root Production. Revista Brasileira de Engenharia Agrícola e Ambiental, 20, 357-363. https://doi.org/10.1590/1807-1929/agriambi.v20n4p357-363

[4] Ferreira, P.P.,Bonfim-Silva, E.M., Silva, T.J.A., Pacheco, A.B., Sousa, H.H.F. and Duarte, T.F. (2017) Density of Soil and Nitrogen in Production and Nutrition of Safflower (Carthamus tinctorius L.). Australian Journal Crop Science, 11, 605-609. https://doi.org/10.21475/ajcs.17.11.05.p436

[5] Spera, S.T., dos Santos, H.P., Fontaneli, R.S. and Dreon, G. (2012) Efeito de sistemas de integração lavoura-pecuária sob plantio direto em alguns atributos físicos do solo. Revista Brasileira de Ciências Agrárias, 7, 388-393.

https://www.embrapa.br/trigo/busca-de-publicacoes/-/publicacao/946188/efeito-desistemas-de-integracao-lavoura-pecuaria-sob-plantio-direto-em-alguns-atributos-fi sicos-do-solo https://doi.org/10.5039/agraria.v7i3a1227

[6] Beutler, A.N., Centurion, J.F., Centurion, M.A.P.C. and Silva, A.P. (2006) Effect of Compaction on Soybean Cultivar Yield in Haplustox. Revista Brasileira Ciência do Solo, 30, 787-794. http://www.scielo.br/pdf/rbcs/v30n5/04.pdf https://doi.org/10.1590/S0100-06832006000500004

[7] Oelke, E.A., Oplinger, E.S., Teynor, T.M., Putnam, D.H., Boneca, J.D., Kelling, K.A., Durgan, B.R. and Noetzel, D.M. (1992) Safflower. Alternative Field Crops Manual. https://www.hort.purdue.edu/newcrop/afcm/safflower.html

[8] Mündel, H.H.,Blackshow, R.E., Byers, J.R., Huang, H.C., Johnson, D.L. and Keon, R. (2004) Safflower Production on the Canadian Prairies. Lethbridge, 1, 1-36.

[9] Handan, Y., Pérez-Vich, B., Velasco, L. and Fernández-Martínez, J.M. (2009) Inheritance of High Oleic Acid Content in Safflower. Euphytica, 168, 1-69.

[10] Coronado, L.M. (2010) El cultivo Del cártamo (Carthamus tinctorius L.) en México. Ms. D. Instituto nacional de investigacion esforestales, agrícolas y pecuárias. México.

[11] Emongor, V. (2010) Safflower (Carthamus tinctorius L.) the Underutilized and Neglected Crop: A Review. Asian Journal of Plant Science, 9, 299-306. https://doi.org/10.3923/ajps.2010.299.306

[12] Abud, H.F., Gonçalves, N.R., Reis, R.G.E., Gallão, M.I. and Innecco, R. (2010) Morphology of Seed and Seedling of Safflower. Revista de Ciências Agronômicas, 41, 259-265. http://ccarevista.ufc.br/seer/index.php/ccarevista/article/view/727

[13] Dajue, L. and Mündel, H.H. (1996) Safflower Carthamus tinctorius L. Promoting the Conservation and Use of Underutilized and Neglected Crops. International Plant Genetic Resources Institute, 1, 1-83.

[14] Gracia, A.B., Márquez, J.P., Camarena, M.G.G., Espinoza, X.M.O., Coronado, L.M. and Cervantes, J.M. (2010) Guíaparaproducion de Cártamoem Sinaloa. Fundación Produce Sinaloa, 1, 1-15. 
[15] Anicésio, E.C.A., Bonfim-Silva, E.M., Silva, T.J.A. and Koetz, M. (2015) Dry Mass, Nutrient Concentration and Accumulation in Safflower (Carthamus tinctorius L.) Influenced by Nitrogen and Potassium Fertilizations. African Journal of Agricultural Research, 9, 552-560. http://www.cropj.com/anicesio_9_6_2015_552_560.pdf

[16] Koutroubas, S.D., Papakosta, D.K. and Doitsinis, A. (2009) Phenotypic Variation in Physiological Determinants of Yield in Spring Sown Safflower under Mediterranean Conditions. Field Crops Research, 112, 199-204. https://doi.org/10.1016/j.fcr.2009.03.002

[17] Empresa Brasileira de Pesquisa Agropecuária (2013) Sistema Brasileiro de Classificação de Solos. Empresa Brasileira de Pesquisa Agropecuária, Brasília.

[18] Silva, G.J., Maia, J.C.S. and Bianchini, A. (2006) Shoot Growth of Plants under Subsurface Irrigation and Four Degrees of Soil Compaction. Revista Brasileira Ciência do Solo, 30, 31-40. https://doi.org/10.1590/S0100-06832006000100004

[19] Ferreira, D.F. (2011) Sisvar: A Computer Statistical Analysis System. Ciência e Agrotecnologia, 35, 1039-1042. https://doi.org/10.1590/S1413-70542011000600001

[20] Bonfim-Silva, E.M., Paludo, J.T.S., Silva, T.J.A. and Guimarães, S.L. (2015) Bulk Density in Jack Bean's Development Grown in Cerrado Oxisol. American Journal of Plant Sciences, 6, 1349-1360. https://doi.org/10.4236/ajps.2015.69134

[21] Gao, W., Hodgkinson, L., Jin, K., Watts, C.W., Ashton, R.W., Shen, J., Ren, T., Dodd, I.C., Binley, A., Phillips, A.L., Hedden, P., Hawkesford, M.J. and Whalley, W.R. (2016) Deep Roots and Soil Structure. Plant Cell Environment, 39, 1662-1668. https://doi.org/10.1111/pce.12684

[22] Mossadeghi-Björklund, M., Arvidsson, J., Keller, T., Koestel, J., Lamandé, M., Larsbo, M. and Jarvis, N. (2016) Effects of Subsoil Compaction on Hydraulic Properties and Preferential Flow in a Swedish Clay Soil. Soil Tillage Research, 156, 91-98. https://doi.org/10.1016/j.still.2015.09.013

[23] Shahrokhnia, M.H. and Sepaskhah, A.R. (2017) Physiologic and Agronomic Traits in Safflower under Various Irrigation Strategies, Planting Methods and Nitrogen Fertilization. Industrial Crops and Products, 95, 126-139. https://doi.org/10.1016/j.indcrop.2016.10.021

[24] Zoz, T. (2012) Correlação e Análise de Trilha de Produtividade em Grãos e Seus Componentes e Caracteres de Planta em Cártamo (Carthamus tinctorius L.) e Mamona (Ricinus communis L.). Master's Thesis, Faculdade de Ciências Agronômicas, Botucatu.

[25] Corleto, A., Alba, E., Polignano, G.B. and Vonghio, G. (1997) A Multipurpose Species with Unexploited Potential and World Adaptability. Proceedings of 4 th International Safflower Conference, Bari, 2-7 June 1997, 373.

[26] Dizaj, K.A. (2007) Stability Analysis of Safflower (Carthamus tinctorius L.) Lines Adaptability in Dryland Conditions in Iran. Revista UDO Agrícola, 7,15-21. https://tspace.library.utoronto.ca/handle/1807/45380

[27] Rocha, E.K. (2005) Fenologia e Qualidade de Carthamus tinctorius L. em Diferentes Populações e Épocas de Cultivo. Master's Thesis, Universidade Federal de Santa Maria, Santa Maria.

[28] Camargo, O.A. and Alleoni, L.R.F. (1997) Compactação do Solo e o Desenvolvimento de Plantas. Luiz de Queiroz College of Agriculture, Piracicaba.

[29] Valicheski, R.R., Grossklaus, F., Stürmer, S.L.K., Tramontin, A.L. and Baade, E.S.A.S. (2012) Growth of Cover Crops and Soybean Yield According to Physical 
Attributes in Compacted Soil. Revista Brasileira de Engenharia Agrícola e Ambiental, 16, 969-977. https://doi.org/10.1590/S1415-43662012000900007

[30] Whalley, W.R., Watts, C.W., Gregory, A.S., Mooney, S.J., Clark, L.J. and Whitmore, A.P. (2008) The Effect of Soil Strength on the Yield of Wheat. Plant Soil, 306, $237-$ 247. https://doi.org/10.1007/s11104-008-9577-5

Submit or recommend next manuscript to SCIRP and we will provide best service for you:

Accepting pre-submission inquiries through Email, Facebook, LinkedIn, Twitter, etc. A wide selection of journals (inclusive of 9 subjects, more than 200 journals) Providing 24-hour high-quality service User-friendly online submission system Fair and swift peer-review system Efficient typesetting and proofreading procedure Display of the result of downloads and visits, as well as the number of cited articles Maximum dissemination of your research work

Submit your manuscript at: http://papersubmission.scirp.org/ Or contact ajps@scirp.org 